\title{
The Determinants of Dividend Payout: Evidence from the Malaysian Property Market
}

\author{
Ong Chun Lin \\ Faculty of Business, Economics and Accounting, \\ HELP University, Malaysia \\ Hassanudin Mohd Thas Thaker \\ Faculty of Business, Economics and Accounting, \\ HELP University, Malaysia \\ Ahmad Khaliq \\ Kulliyyah of Economics and Management Sciences, \\ International Islamic University Malaysia (IIUM) \\ Mohamed Asmy Mohd Thas Thaker \\ Kulliyyah of Economics and Management Sciences, \\ International Islamic University Malaysia (IIUM) \\ Email: hassanudinmtt@help.edu.my
}

\begin{abstract}
The paper aims to investigate the determinants of dividend payout among the Malaysian property companies. The sample size consists of 30 property listed companies on Bursa Malaysia. The data are generally obtained from the company's annual report for the period of 2012 to 2016. The study employs multiple regression analysis to examine the influence of firms specific and macroeconomic variables on dividend payout. Result of the test shows that the dividend payout has a significant negative relationship with ownership structure

Keywords:

Property Market, and Malaysia and positive relationship on return on equity, quick ratio and GDP. The study instigates to enrich the literature on dividend determinants especially in the context of Malaysia.
\end{abstract}




\section{INTRODUCTION}

The study instigates to identify the determining factor of dividend payout on public listed property companies in Malaysia for the period of 2012 to 2016. Nine determinant variables were prudently selected which are ownership structure, the age of corporation, market capitalization, leverage, profitability, liquidity, taxation policy, inflation, and gross domestic product (GDP). These variables were taken into consideration in order to examine the effect on dividend payout policy. It is found that different company employs a different dividend payout policy whereby the dividend payout decisions are usually made by the management team based on company performance and human behavior intervention.

In 2016, the economy of Malaysia had recorded a growth rate of $4.2 \%$ which there is a significant decrease in growth rate compared to $5.0 \%$ of growth rate in 2015 because of considerable external and domestic headwinds, driven mainly by the unforeseen political changed in the developed economy, such as the UK and US, and the economic policies accepted by these economies. Locally, the economy keeps on face headwinds from the higher cost of living in the midst of soft employment conditions. However, even in those international and domestic difficulties, the economy of Malaysia found to expand modestly during the year.

Figure 1.0: MHPI Quarterly Trend Q1 2000 - Q4P 2014

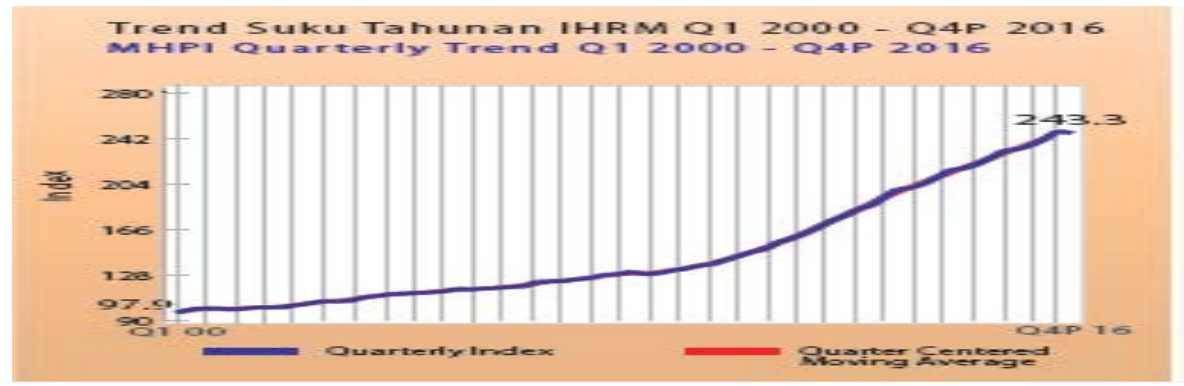

Note: This Figure shows the Malaysia Housing Price Index, as at $4^{\text {th }}$ quarter 2016. This figure was extracted from the Department of Statistics, Malaysia. Looking at the figure, it is very clear that MHPI shows an upward trend from Q12000 until Q42016.

Figure 1.0 shows that Malaysia housing price index (HPI) has been going up tremendously, housing price index is a measure of the movement of house prices in Malaysia from 
serving as an indicator of house price trends. In the last decade, Malaysia's housing price index had increased 100\% from the year 2007 (123.4index or RM170, 8884) to 2016 (243.3index or RM337, 096). In the year 2009, the housing price index annual growth rate is $1.5 \%$, this is the effect of the global financial crisis 2007-2008. While in the year 2012, the property market annual growth rate is the highest growth rate since the year 2000, which is $11.8 \%$ and followed by $11.6 \%$ in the year 2013 and $9.9 \%$ in the year 2011. This drastically increase was an indicator that property market has recovered from the great recession year 2008.

The private sector remained the key driver of growth. The private sector includes individual buying a house and the individual consumption growth rate was maintained at $6.1 \%$ (2015:6.0\%), the reason that the house buying rate remained in average $6 \%$ is due to the increase of employment rate and wage growth following the increase in the lowest wage permitted by law. The government also used another policy to support the housing market, for example, allowed people who want to buy a new house by using their second saving accounts in Employees Provident Fund (EPF).

There are sub-sectors in property market such as residential property, agricultural, commercial, industrial, and development land. Residential property is the largest sub-sectors which have $64.6 \%$ of the total share in the year 2013, followed by agriculture $(18.5 \%)$, commercial $(9.0 \%)$, development land $(5.6 \%)$, and industrial (2.2\%). (Rehda, 2014).

Residential property can be considered as the major player in real property markets and the property has turned into an attractive investment asset. Survey results from visitors to the iproperty.com website from $5^{\text {th }}$ July to $8^{\text {th }}$ August 2016 showed that the survey consists of 4,678 Malaysian respondents, majority of respondents (36\%) own a property, $21 \%$ own two or more properties, $26 \%$ of respondents are first-time home buyers, while $27 \%$ of the respondents do not own any property. But this is a quite low rate as compared to Indonesia (49\%) and Hong Kong (57\%), half of the residents in these two places do not own a property to live in. (iproperty.com, 2016).

In recent years, Malaysia government has launched a few of huge projects and open tenders to local or China property companies, and the projects are believed to improve Malaysia economy in the near future. For example, Bandar Malaysia 
in Kuala Lumpur (KL), Forest City in Johor Bahru (JB), Carey Island in Port Klang, and Melaka gateway. Melaka gateway is a joint venture project between Malaysia and China that estimated to cost about RM40 billion and the Chinese company (EPC) has been successfully winning the tender. Melaka gateway will expectedly replace Singapore to become the biggest port in South East Asia after its completion. Bandar Malaysia is the last biggest land that is developed in $\mathrm{KL}$, and the potential value of Bandar Malaysia has increased since it launched. All the project contains residential zone, commercial zone, industrial zone, and entertainment zone, which carries the concept of having an individual small-scale city by itself in the enormous city like KL.

Figure 2.0: Housing Loans Trends

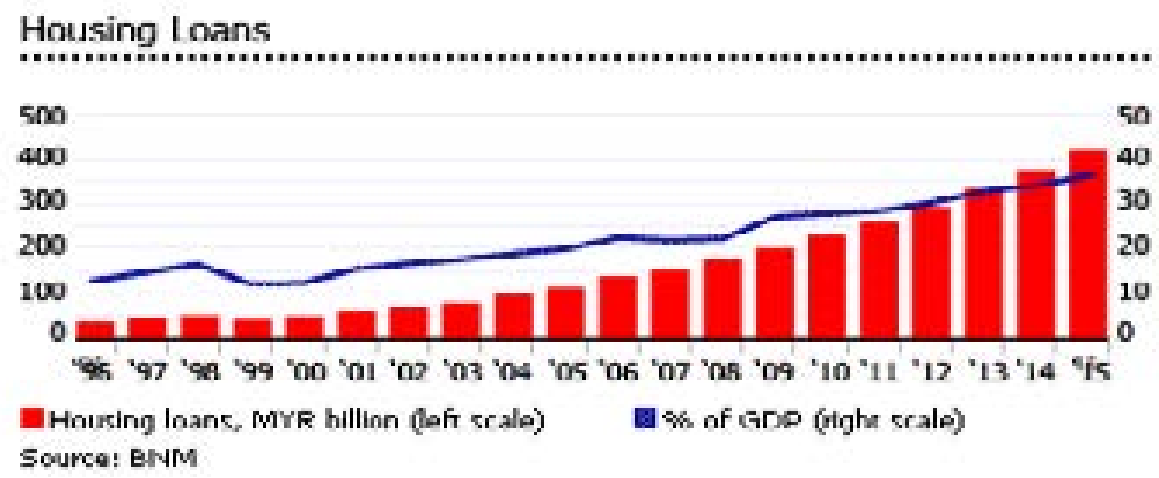

Note: This figure shows the housing loans statistics in Malaysia from the year 1996 till 2015. The housing rate increased as the GDP increasing.

The increasing of housing price index is undeniably a burden to residents, especially those who are in the lowest income group. Besides, the housing market is not readily available to provide an adequate supply of affordable housing for the masses. This undersupply of an affordable house is probably going to worsen given current movement in income and demographic factors. This is significantly a burden to people who are not able to buy a house as their monthly income cannot afford to pay the housing loan and sustain a decent living environment at the same time. However, several types of bank financing for the purchasing of residential properties for qualified borrowers have been introduced subsequently. Figure 1.2 shows that the housing loan is increasing continuously every year and reached over RM 400 billion or $35 \%$ of GDP in the 
year 2015. The applications of housing loan also fell further to a rejection rate of $23.6 \%$ in 2016 as compared to $26.1 \%$ in 2015 . The statistic implied that the housing loan sufficiently remains to qualified home buyers.

House is a basic need for everyone because this is an asset that can provide the space for living and protect the people away from the extreme and adverse weather. A country like Malaysia with an emerging economy still can manage to increase at a flat rate despite the global economy which is relatively unstable due to numbers of uncertainty factors. Property market can be treated as running alongside the economy of the country. The property is tangible and attractive assets that it can use to hedge against the inflation. These factors are the driven to make the growth of property industry in Malaysia. Given such rapid development in the property market of Malaysia, it would be fascinating to investigate the performance of property companies especially with regards to respective dividend payout policies. Hence, to answer this question, it is important to know what determines the dividend payout among property companies in Malaysia. The study claims two contributions, firstly, this study enriches the existing literature in the area of dividend payout policy particularly in property markets of Malaysia as there is a scanty number of studies explore on the Malaysian property market. Secondly, the study also elucidates the warm debates on the determinants of dividend payout policies which remain unresolved and not harmonized.

\section{LITERATURE REVIEW}

It is opined that the dividends have no impact on share price in a perfect world without personal taxes and transaction costs (Modigliani and Miller, 1961). Ross et al. (1999) further complement that the share price of a company or the company value are not ominously influenced by the declaration of dividend, but rather will be affected by the ability of the company's earning and the risk classifications of the assets. They questioned that the loss of capital to current shareholders is because of an increase in dividend and these two will offset each other. The changing of dividend had been hypothesized as the tradeoff between the current income and the selling price of the future. M.J. Gordon (1963) "bird in the hand" theory opined that a number of investors favour dividend payment more than the potential capital gains of stocks. The dividend can regard as 
cash in hand and capital gain regard like the two birds in the bushes. In this way, if capital earnings are risky but the dividend is safe, the company will pay a high dividend payout and cause the investors to discount the higher dividend stream at a lower required rate of return. Thus, the share price and firm value will increase.

According to Litzenberger and Ramaswamy (1979), they claimed that investors inclined toward low pay-out company to avoid paying the tax. The argument depends on the assumption that dividends are tax at higher rate compare to taxes on capital gains. Dividends are taxed in the year they received while capital gains are taxed when selling the stock. By utilizing the concept of time value of money, current dividends have more effect on capital cost than capital gains in future. This theory reiterates that dividend policy can influence the share price since shareholder prefer retained earnings to current dividends. Different from M\&M, this theory has considered on taxes in the real world.

In a study done by Walter (1963), he focuses on examined net cash flows position and considered the effects of additions or subtractions from these flows. The finding of this study verified that there are two factors can influence on share price, which is afinite flow of dividends stream and terminal market values. He concluded that the decision of dividend policy will always influence the value of an enterprise as the general conditions for neutrality are unrealistic in the real world where markets are imperfect and suggested that growth firms should retain all earnings.

\section{Literature on Impacts of Determinants on Dividend Payout}

Numerous studies initiated to determine the precise factor that significantly contributes to the dividend policy payout in numbers of corporate companies. For instance, Horace (2003) evaluated the dividend policy for listed companies in Australia and Japan. The data of the study was retrieved from the constituent stock of Japanese stock market Nikkei 225 Index and the Australian ASX 200 Index. While utilizing the fixed effect regression model to inspect the hypothesis, the result of the study concluded that the size of the firm had a positive significant impact for Australian companies, while the liquidity element had a positive significant impact for companies in Japan. The later, Luciana and Aydin (2006) study the 
relationship between ownership and dividend payout of listed firms in the Italian market. With the sample size of one hundred and thirty-nine listed Italian companies, the study measures the ownership structure of firm based on the voting rights of large shareholders. The result indicated that there is a negative relationship between ownership structure and dividend payout. When the voting rights of the shareholder increased, it is found that the organizations theoretically have a low rate to announce thedividend payout. Few et al. (2008) examined the relationship between numerous determinants and dividend payout in Malaysian listed companies. The sample of the study which consists of one hundred companies randomly selected from Bursa Malaysia for the period of 2002 until 2005. The study revealed that the return on asset (ROA) and return on equity (ROE) shows a strong positive relationship with dividend policy, while the firm leverage shows a strong negative relationship with dividend policy. Tobias (2009), the study utilized cointegration test to examine the relationship of dividend payout and inflation in Australia. The cointegration test is developed by Johansen (1991) to analyse a long run relationship between two variables. The study found that dividend payout has a stable long-run relationship with inflation in Australia.

According to the study of Amarjit et al. (2010), the study examined the determinants impact on dividend payout for US service and manufacturing firms. The independent variables included in this study were profitability, cash flow, sales growth, leverage and tax. The study concluded that dividend payout is the function of profitability and tax. Further, George and Yikang (2011) study on the effect of the tax change on dividend payout. The study employs four hundred and sixtyseven companies in S\&P 500 for a period 1984 to 2002. The study assumed dividend payout is depending on many factors, such as profitability, investment opportunity and size. Based on this, the study tried to figure out the relationship between dividend and applicable tax rates. The study concluded that profitability is the only factor to explain the negative relationship between dividend and tax rate. The more profitable the firms are, the more likely they pay higher dividends as applicable tax rate declines. Moreover, Basse and Reddemann (2011) investigated the relationship of inflation with dividend policy in the US. The study has examined five hundred leading companies in the US and concluded that dividend payout has a stable long-run 
relationship with inflation.

Later in 2012, Ayman (2012) investigated the relationship between selected determinants and dividend payout policy for Malaysian listed companies. Two hundred and eighty-four firms listed on the Bursa Malaysia were selected as the sample size of the study. The result indicated that return on assets (ROA), return on equity (ROE), earnings per share (EPS), and market capitalization had a substantial positive relationship with dividend payout, while the free cash flow has a negative weighty influence on dividend payout. In addition, Daniela (2014) investigated the causality of dividends and economic growth in Germany and Netherlands. Economic growth is measured by the yearly growth of real GDP. The data of thirty companies that trade in the most important stock market indexes of each country for a period of 2003 to 2012 were collected. Stationarity test, cointegration test and Granger-causality test have been applied in the study. The research implied that the economic growth has an influence on a dividend payout of listed companies of the country.

Later, Yusniliyana and Suhaiza (2016) examined on the factor influence dividend policy in Malaysia. The sample of the study consists of one hundred and forty-seven listed companies. The independent variables are earnings, cash flow, free cash flow, leverage, investment, market capitalization proxy as firm size, ownership structure, risk and lagged dividend. After a series of analyses, the finding of the study elucidates that the earnings, firm size and investment have a significant positive impact as deciding factor for dividend policy, while leverage and ownership structure have a significant negative effect on dividend policy.

In advanced, Nurul et al. (2016) examined the factors that can influence dividend policy on non-financial and financial firms in Malaysia. The most profitability and high dividend firms have been selected in this study cover a period from 2005 to 2014. The finding of the study indicated that dividend policy for both non-financial and financial companies was significantly affected by growth rate, profitability and firm size. On the other hand, dividend policy of financial firm is influenced by firm size, profitability and liquidity, while dividend policy of non-financial firm is influenced by profitability and growth. To clarify further, a study carried out by Yong and Mazlina (2016) investigated on factors affecting the dividend payout by Malaysians listed 
firms. The sample size of the study was taken for the sum of one hundred, out of eight hundred and fifty-four companies listed on Bursa Malaysia. While employing the multiple regression to discover the influence of factor determining the dividend payout, the result of the study discovered that firm size, liquidity and investment opportunities have a significant positive effect on dividend payout.

It is noted from numbers of literature above that there is aprevalent possibility to elucidate the determining factors for dividend payout policy practice by corporate entities. Hence, this study attempt to fill the research gap while at the same time act as a supplement for corporate entities in making a responsive resolution with regards to dividend payout policy towards attaining inordinate company value and growth.

\section{RESEARCH METHOD}

To categorize the affiliation between dividend payout and share price, all relevant informations affecting dividend payout were collected. All the required data in this study are secondary data, which is also known as an auxiliary data. Secondary data is defined as data that already existed and is used either to verify new research or justify previous findings. Secondary data can be easily obtained from the internet and are available as open access to the public. Total of twelve elements comprise of firms specific and macroeconomic variables have been selected entail of dividend payout, ownership structure, the age of corporation, market capitalization, leverage ratio, $\mathrm{ROA}, \mathrm{ROE}$, current ratio, quick ratio, taxation policy, inflation (CPI) and GDP. The first six variables were collected from the annual report of thirty selected property companies listed on Bursa Malaysia, and the rest of data will be collected from Yahoo finance and Trading economic websites.

Table 1: Data Measurement (Period: 2012-2016)

\begin{tabular}{|l|l|l|l|l|}
\hline No. & Variables & Proxy & Unit & Source \\
\hline 1. & Ownership structure & Own & $\begin{array}{l}\text { 1=Concentrat- } \\
\text { ed } \\
\text { 2=Dispersed }\end{array}$ & Annual report \\
\hline 2. & Age of corporation & Age & Figure & Annual report \\
\hline 3. & Market Capitalization & MC & in Millions & Annual report \\
\hline 4. & Leverage & LR & Percentage & Annual report \\
\hline
\end{tabular}




\begin{tabular}{|l|l|l|l|l|}
\hline 5. & $\begin{array}{l}\text { Profitability (ROA and } \\
\text { ROE) ratio }\end{array}$ & $\begin{array}{l}\text { ROA } \\
\text { ROE }\end{array}$ & Percentage & Annual report \\
\hline 6. & $\begin{array}{l}\text { Liquidity (current and } \\
\text { quick) ratio }\end{array}$ & $\begin{array}{l}\text { CR } \\
\text { QR }\end{array}$ & Times & Annual report \\
\hline 7. & Taxation policy & TAX & Percentage & $\begin{array}{l}\text { Trading eco- } \\
\text { nomic website }\end{array}$ \\
\hline 8. & $\begin{array}{l}\text { Inflation (Consumer } \\
\text { price index) }\end{array}$ & INF & $\begin{array}{l}\text { Index } \\
(2010=100)\end{array}$ & Yahoo Finance \\
\hline 9. & Gross Domestic Product & GDP & Billions & $\begin{array}{l}\text { Trading eco- } \\
\text { nomic website }\end{array}$ \\
\hline 10. & Dividend Payout & DIV & MYR & Yahoo Finance \\
\hline
\end{tabular}

Note: Table above indicate the selection of the variables used for this study. In sum, variables amounted to twelve elements inclusive of the dependent variable. Greater number of data is taken from the Trading Economic, Annual Report and Yahoo Finance webpage. The time span applied for the study are from 2012 to 2016.

To recall back, the objective of this paper is to examine the determinants of dividend payout. Thus, the multiple regressions are engaged to predict each variable's value. To identify and evaluate the relationship of variables and dividend payout, the study apply the multiple regression model. The dependent variables denote for dividend payout and the rest as independent variables. Below depicts the formula generated of this regression model:

$$
\begin{aligned}
& \mathrm{DIV}=\beta_{0}+\beta_{1}(\mathrm{OWN})+\beta_{2}(\mathrm{AGE})+\beta_{3}(\mathrm{MC})+\beta_{4}(\mathrm{LR})+\beta_{5}(\mathrm{ROA})+\beta_{6} \\
& (\mathrm{ROE})+\beta_{7}(\mathrm{CR})+\beta_{8}(\mathrm{QR})+\beta_{9}(\mathrm{TAX})+\beta_{10}(\mathrm{INF})+\beta_{11}(\mathrm{GDP})+{ }_{c t} \\
& {[1]}
\end{aligned}
$$

\section{FINDINGS AND DISCUSSIONS}

\section{Descriptive Statistics}

Table 2 illustrate the summary table of mean and standard deviation of dependent and independent variables for 30 property companies in Malaysia with 140 perceptions for a period of 2012 to 2016. Table 4.1 shows us that the average dividend payout of 30 property companies is RM0.059126 and the standard deviation of RM0.0494151. In other words, the normal dividend payout is RM0.0591226 
and vacillates inside of the scope of RM0.0494151 far from mean. The mean of age of company is 39.44 and standard deviation of the age of company is 23.258 which implies that the normal age of company is 39.44 and vacillates inside of the scope of 23.258 far from mean. The mean of market capitalization is 890.38 millions and standard deviation of market capitalization is 1047.953 millions. It means that the normal market capitalization is 890.38 millions and vacillates inside of the scope of 1047.953millions far from mean. The mean of Inflation is 111.7614 index and standard deviation of inflation is 3.83386 index. This shows that the normal inflation is 111.7614 index and vacillates inside of the scope of 3.83386 indexes far from the mean. The mean of gross domestic product is 316.06983 billions and standard deviation of GDP is 14.219675billions. This result indicates that the normal gross domestic product is 316.06983 billions and vacillates inside of the scope of 14.219675billions far from mean.

The mean of return on assets is $5.8733 \%$ and standard deviation of return on assets is $3.74335 \%$. Which shows that the normal return on assets is $5.8733 \%$ and vacillates inside of the scope of $3.74335 \%$ far from mean. The results portray that the mean of return on equity amounted $10.4116 \%$ and the standard deviation for return on equity is totaled to $7.57978 \%$. It means that normal return on equity is $10.4116 \%$ and vacillates inside of the scope of $7.57978 \%$ far from mean. The mean of current ratio is 2.3854times and standard deviation of current ratio is 1.10314times. It means that normal current ratio is 2.3854times and vacillates inside of the scope of 1.10314times far from the mean. The mean of the quick ratio is 2.0953times and standard deviation of the quick ratio is 1.11733times. It means that normal quick ratio is 2.0953 times and vacillates inside of the scope of 1.11733 times far from the mean. The mean of leverage is $33.7485 \%$ and standard deviation of leverage is $35.38400 \%$. It means that normal leverage is $33.7485 \%$ and vacillates inside of the scope of $35.38400 \%$ far from mean. The mean of the tax rate is $24.7929 \%$ and standard deviation of the tax rate is $0.40671 \%$. It means that normal tax rate is $24.7929 \%$ and vacillates inside of the scope of $0.40671 \%$ far from mean. 
Table 2: Descriptive Statistics

\begin{tabular}{|l|r|r|r|}
\hline Variables & Mean & Std. Deviation & $\mathrm{N}$ \\
\hline DIV & 0.05912 & 0.0494151 & 140 \\
\hline AGE & 39.44 & 23.258 & 140 \\
\hline OWN & 1.57 & 0.497 & 140 \\
\hline MC & 890.38 & $1,047.953$ & 140 \\
\hline INF & 111.761 & 3.83386 & 140 \\
\hline GDP & 316.069 & 14.219675 & 140 \\
\hline ROA & 0.05873 & 0.0374335 & 140 \\
\hline ROE & 0.10411 & 0.0757978 & 140 \\
\hline CR & 2.3854 & 1.10314 & 140 \\
\hline QR & 2.0953 & 1.11733 & 140 \\
\hline LR & .337485 & 0.3538400 & 140 \\
\hline TAX & .247929 & 0.0040671 & 140 \\
\hline
\end{tabular}

Note: Table above demonstrate the descriptive statistics for the variables selected. Data Measurement covers from the year2012 to 2016. All together there are twelve variables used in this study including the dependent variables.

\section{Pearson Correlation}

The Pearson Correlation table above shows the correlation of each variable in this study. The table portrays that gross domestic product, return on asset and return on equity have a significant positive correlation with dividend payout at various significance level. The ownership structure and leverage ratio have a significant negative correlation to dividend payout holding the value of -0.142 and -0.248 singly. The market capitalization, age of the company and inflation shows a negative correlation to dividend payout at the value of $-0.042,-0.043$ and -0.064 respectively. Quick ratio, current ratio and tax rate have a positive correlation to dividend payout at the value of $0.067,0.101$ and 0.108 correspondingly. Furthermore, the correlation analysis also postulates that none of the variables having a strong correlation and confirming that the data used are fit for the research purpose. It means there is no existence of multicollinearity problem in the data used. 
Table 3: Correlations Analysis

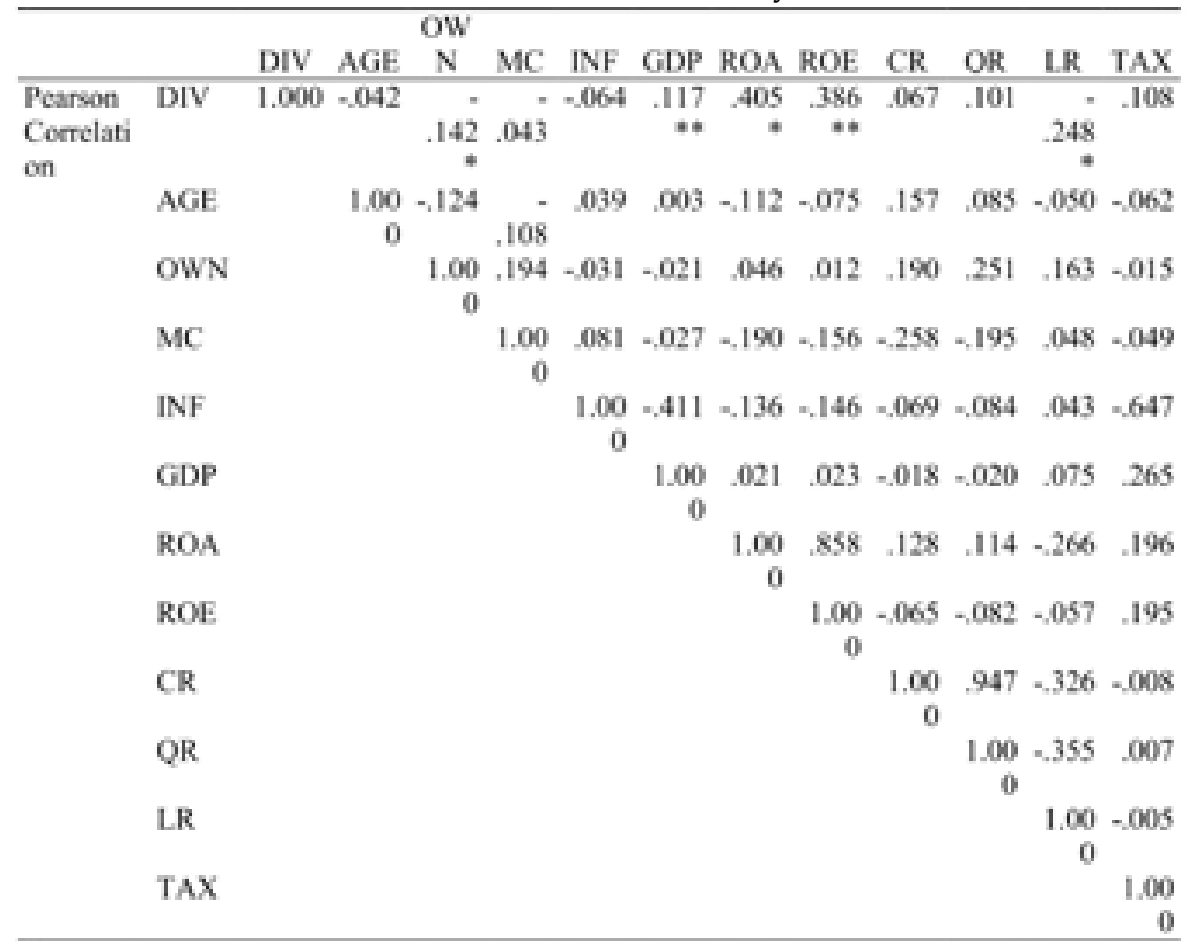

Note: This table reveals the correlation analysis for the selected variables. Looking at the correlation analysis, it is very clear that none of the variables having a strong correlation and confirming that the data used is fit for the research purpose.Data Measurement covering from the year20122016 and there are twelve variables used including the dependent variable. The cryptograms * ${ }^{* *},{ }^{* * *}$ symbolizes significant level at $10 \%, 5 \%$ and $1 \%$ respectively.

\section{Regression Analysis \\ Model Summary}

In Table 4, the $\mathrm{R}$ represents the coefficients of multiple correlations. The coefficient of multiple determination for multiple regression which commonly identified as $\mathrm{R}$ square. The value of $R$ square in this model is found at the value of 0.264 and it denotes that the dividend payout record for $26.4 \%$ of the difference in the determinants. Dividend payout in this model was explained by the dependent variables are $26.4 \%$. The Durbin - Watson of 1.181 reveals that the model is not suffering the multicollinearity problem. 
Table 4: Model Summary

\begin{tabular}{|c|c|c|c|c|c|}
\hline $\begin{array}{c}\text { Mod- } \\
\text { el }\end{array}$ & $\mathrm{R}$ & $\begin{array}{c}\mathrm{R} \\
\text { Square }\end{array}$ & $\begin{array}{c}\text { Adjusted R } \\
\text { Square }\end{array}$ & $\begin{array}{c}\text { Std. Error of } \\
\text { the Estimate }\end{array}$ & $\begin{array}{c}\text { Durbin-Wat- } \\
\text { son }\end{array}$ \\
\hline 1 & $.513^{\mathrm{a}}$ & .264 & .200 & 0.0441884 & 1.181 \\
\hline
\end{tabular}

Note: This table shows the overall model summary with the R-Square value of $51.3 \%$ and the Durbin - Watson of 1.181 confirming that there is no multicollinearity problem in the data.

From the ANOVA analysis, the significant value is 0.00 , which is less than 5 percent of significant level. The ANOVA test further indicated that it is a solid match model, so there is a significant statistical differences in the dividend payout amongst the predictors taken.

Table 5: Anova

\begin{tabular}{|l|l|c|c|c|c|c|}
\hline \multicolumn{2}{|l|}{ Model } & $\begin{array}{c}\text { Sum of } \\
\text { Squares }\end{array}$ & $\mathrm{df}$ & $\begin{array}{c}\text { Mean } \\
\text { Square }\end{array}$ & $\mathrm{F}$ & Sig. \\
\hline \multirow{3}{*}{1} & Regression & .089 & 11 & .008 & 4.166 & $.000^{* *}$ \\
\cline { 2 - 7 } & Residual & .250 & 128 & .002 & & \\
\cline { 2 - 7 } & Total & .339 & 139 & & & \\
\hline
\end{tabular}

Note: The table shows for Anova analysis by the model developed in this study. Looking at this table, it tells that at least one variable is significantly correlated to the dividend payout. Given this, the multiple regression can be carried out. The signs of ****,*** denotes significant at $10 \%, 5 \%$ and $1 \%$ respectively.

\section{Coefficient Analysis}

Table 6 below indicates the multiple regression model results for dependent variables and the independent variable with consideration to the specimen of 140 for a period of 2012 to 2016.

Table 6: Coefficient Analysis

\begin{tabular}{|c|c|r|c|c|c|}
\hline Model & \multicolumn{2}{|c|}{$\begin{array}{c}\text { Unstandardized } \\
\text { B }\end{array}$} & $\begin{array}{c}\text { Standard- } \\
\text { ized Coef- } \\
\text { ficients }\end{array}$ & & \\
\cline { 2 - 4 } & $\begin{array}{c}\text { Std. } \\
\text { Error }\end{array}$ & Beta & & $\mathrm{t}$ & Sig. \\
\hline
\end{tabular}




\begin{tabular}{|l|l|r|r|r|r|c|}
\hline 1 & $\begin{array}{l}\text { (Con- } \\
\text { stant) }\end{array}$ & -0.349 & 0.439 & & -0.7940 & 0.428 \\
\cline { 2 - 7 } & AGE & $\begin{array}{r}-3.055 \mathrm{E}- \\
5\end{array}$ & 0.000 & -0.014 & -0.1790 & 0.858 \\
\cline { 2 - 7 } & OWN & -0.019 & 0.009 & -0.188 & -2.158 & $0.033^{* *}$ \\
\hline MC & $3.210 \mathrm{E}-6$ & 0.000 & 0.068 & 0.8100 & 0.419 \\
\hline INF & 0.001 & 0.001 & 0.091 & 0.8530 & 0.395 \\
\hline GDP & 0.001 & 0.000 & 0.146 & 1.7430 & $0.084^{*}$ \\
\hline ROA & 0.158 & 0.228 & 0.120 & 0.6920 & 0.490 \\
\hline ROE & 0.199 & 0.108 & 0.306 & 1.8490 & $0.067^{*}$ \\
\hline CR & -0.016 & 0.011 & -0.352 & -1.404 & 0.163 \\
\hline QR & 0.021 & 0.011 & 0.470 & 1.8560 & $0.066^{*}$ \\
\hline LR & -0.019 & 0.013 & -0.135 & -1.458 & 0.147 \\
\hline & TAX & 0.461 & 1.232 & 0.038 & 0.3740 & 0.709 \\
\hline
\end{tabular}

Note: This table shows the coefficient analysis for the variables selected. Out of eleven variables, only four variables are found to be significant. The symbols of *, **, *** represents significant level at $10 \%, 5 \%$ and $1 \%$ respectively.

From the table 6 above, it illustrates that the ownership structure possesses a sturdy negative relationship to the dividend payout of the Malaysian property market for the period of 2012 to 2016 as its t-statistic reaches -2.158 , beta -0.019 and it is statistically significant at 0.033 with dividend payout at $10 \%$ significant level. This suggests that we reject $\mathrm{H}_{0}$ and accept alternative hypothesis $\mathrm{H}_{1}$. As the voting rights of large shareholders' increase, the firm is more concentration and will make lower dividend payout. This finding indicate the same results to study of Luciana and Aydin (2006) which settled that ownership structure has a negative significant relationship with dividend payout. The reason why when ownership structure is concentrated and prefer lower dividend payout is probably because the company in Malaysia favourskeeping more retained earnings for expansion than pay as a dividend. Moreover, a negative indication of $t$-value and regression coefficient of the age of company at -0.00003055 designates that the age of company has a weak negative influence to the dividend payout although it does not statistically significant at $10 \%$ significant level. The result in this study devotes that it failed to reject the 
null hypothesis as there found no concrete evidence to settle that age of company is negatively related to dividend payout.

The market capitalization treats as a proxy for firm size. The regression coefficient of 0.0000321 and positive indication of $t$-value indicates that the market capitalization has a weak positive relationship with dividend payout. The leverage has a negative regression coefficient and $t$-value figure out that the leverage is weakly related to dividend payout. Both of market capitalization and leverage variables are not statistically significant at $10 \%$ significant level. Therefore, the market capitalization and leverage have no impact on dividend payout.

The profitability indicator of the corporate entity are ordinarily denoted by return on asset and return on equity. In this study, return on asset and return on equity illustrate for positive regression coefficient at the value of 0.158 and 0.199 respectively. This simply outline that ROA and ROE positively affect the dividend payout. The p-value of 0.490 and 0.067 of ROA and ROE respectively signifies that the return on asset is not statistically significant to dividend payout but the return on equity is statistically significant influence the dividend payout. So, it can be concluding that the return on equity has a significant positive relationship with dividend payout in Malaysia property market. This finding is supported by the study of Ling et al. (2008) and Issa (2015), which exhibited that return on equity has a resilient positive relationship towards dividend payout for Malaysian listed corporations. This indicates that when the property companies in Malaysia have more return on their equity, they prefer to pay back to their shareholders by publicizing the dividend payout.

The liquidity of the company commonly represented by current ratio and quick ratio. The coefficient table demonstrates that the coefficient of current ratio and quick ratio are -0.016 and 0.021 respectively. The result designates that current ratio is not statistically significant whereas the quick ratio is statistically significant to the dividend payout at $10 \%$ significant level. In general, this study settles that quick ratio has a positive significant effect on dividend payout. This finding is similar to Horace (2003), which opined that dividend payout policy is positively affected as a result of liquidity state of the company. This revealed that when the property companies in Malaysia have more cash than usual, it will pay a dividend to shareholders rather than pay to tax authorities. 
Tax rate and inflation both have a positive indication of $\mathrm{t}$-value and regression coefficient of 0.461 and 0.001 respectively. This devotes that tax rate and inflation partake a positive affiliation to dividend payout. Nevertheless, both variables are seen as not statistically significant at $10 \%$ significant level. The outcome of this study tells that the tax rate and inflation have a positive insignificant relationship to dividend payout.

From the table 6 above, positive indication of $t$-value and regression coefficient at 0.001 of gross domestic product are illustrated by this study. This simply specifies that GDP has a positive influence to dividend payout, and it is statistically significant at $10 \%$ significant level. Thus, this study settles that GDP possess a significant positiverelationship to a dividend payout policy for property companies in Malaysian market. This finding is parallel to Daniela (2014) who found that the GDP growth has an affirmative effect on dividend payout. Growth in GDP means that the Malaysian economy experience an expansion during the year, the market was more active than last year, so the property company will probably make a profit due to the expansion of the economy. Thus, the company will pay a dividend when it is earning and have more cash to pay to shareholders.

In this study, ownership structure, ROE, quick ratio and GDP have a significant influence on dividend payout. Entirely the variables included in the equation and substitute the coefficient, $\beta$ into equation. The multiple regression model as follow:

Unstandardized Equation
$\overline{\mathrm{DIV}}=0.3490 .019(\mathrm{OWN})+0.199(\mathrm{ROE})+0.021(\mathrm{QR})+0.001$ (GDP)

Standardized Equation

$\mathrm{DIV}=0.188(\mathrm{OWN})+0.306(\mathrm{ROE})+0.470(\mathrm{QR})+0.146(\mathrm{GDP})$

\section{CONCLUSION AND POLICY IMPLICATIONS}

This study attempt to identify the determinants of dividend payout among the Malaysian property companies. The time framework used is from 2012 to 2016 and the multiple regression was utilized to capture the relationship. The finding shows that return on equity, quick ratio and gross domestic product have a significant positive relationship towards dividend payout. It simply indicate that when any of these elements increases, the 
dividend will also increase at its specified pace. Ownership structure possess a significant negative relationship to dividend payout. This can also be interpreted as when the firm is more concentrated, the lower dividend payout guidelines will uphold by the firm. Market capitalization, return on asset, tax rate and inflation shows a positive relationship to dividend payout even though they are not statistically significant at $10 \%$ significant level. Age of corporation, leverage and current ratio showed a negative relationship towards dividend payout although it is not statistically significant at $10 \%$ significant level. In light of these findings, it is worthwhile for the investor to consider the property companies for the investment purpose. As for future research, the future research may incorporate the external such as cash flow, changes in government policies, trend of profits and legal rules may have a relationship with dividend payout.

This study has one theoretical implication where the outcome of this study is expected to enrich the body of knowledge particularly in the field of dividend literature. Although in Malaysia, there are studies that dealings with the dividend theories and policies but in terms of property market, it is under explored in the context of Malaysia. Knowing the variable that affecting the dividend payout among the property companies, investors would be able design better investment strategy when making investment decision. 


\section{REFERENCES}

Amarjit, G. Nahum, B., Rajendra, T. (2010). Determinants of Dividend Payout Ratios: Evidence from the United States. The Open Business Journal, 3(6), 08-14.

Ayman, I. Issa, F. (2012). The Determinants of Dividend Policy: Evidence from Malaysian Firms. Research Journal of Finance and Accounting, 6(18), 01 - 15.

Basse, T. Reddemann, S. (2011). Inflation and Dividend Policy of Us Firms. Managerial Finance, 37(1), 34 - 46.

Daniela, R. M. (2014). The causal relationship between dividends and economic growth: An analysis for Germany and the Netherlands. Available online http:/ / scriptie-online.ube. uva.nl/document/585058. [Accessed on April 23, 2017]

Few, S.L., Mutalip, M.L.A., Shahrin, A.R., \&Othman, M.S. (2008). Dividend Policy: Evidence from Public Listed Companies in Malaysia. International Review of Business Research Papers, 4(4), 208-222.

Gordon, M.J. (1963). Optimal Investment and Financing Policy. Journal of Finance, 18(2), 264-272.

Horace, H. (2003). Dividend Policies in Australia and Japan. International Advances in Economic Research, 9(2), 91-100.

Issa, A. (2015). The Determinants of Dividend Policy: Evidence from Malaysian Firms. Research Journal of Finance and Accounting, 6(1), 1-19.

Jabbour, G.M. \& Liu, Y. (2011). The effect of tax rate change on dividend payout. Journal of Business $\mathcal{E}$ Economics Research (JBER), 2(10), 1-19.

Johansen, S. (1991). Estimation and hypothesis testing of cointegration vectors in Gaussian vector autoregressive models. Econometrica: Journal of the Econometric Society, 59(6), 1551-1580. 
Ling, F.S., AbdullMutalip, M.L., Shahrin, A.R.,\& Othman, M.S. (2007). Dividend policy: evidence from public listed companies in Malaysia. International Review of Business Research Papers, 4(4), 208-222.

Litzenberger, R.H. \&Ramaswamy, K. (1979). The Effects of Personal Taxes and Dividends on Capital Assets Prices: Theory and Empirical Evidence. Journal of Financial Economics, l7(2), 163-195.

Luciana, M. \& Aydin, O. (2006). Ownership structure and dividend policy: Evidence from Italian firms. The European Journal of Finance, 12(3), 20 -36.

Miller, M.H. \& Modigliani, F. (1961). Dividend policy, growth, and the valuation of shares. The Journal of Business, 34(4), 411-433.

Nurul, F.M., Suhana. M., Nurul, A., \&Nur,A,F, (2016). Modeling of Dividend Policy: A Comparison between Malaysia Financial and Non-Financial Industries. Journal of Applied Environmental and Biological Sciences, 6(7), 48-51.

Ross, S.E., Niebling, L.C., \&Heckert, T.M. (1999). Sources of stress among college students. Coll. Stud. J, 33(1), 312-317.

Tobias, B. (2009). Dividend Policy and Inflation in Australia: Results from Cointegration Tests.International Journal of Business and Management, 4(6), 13-16.

Walter, J. (1963). Dividend Policy: Its Influence on the Value of the Enterprise. The Journal of Finance, 18(2), 280 - 291.

Yong, T.M. \& Mazlina, M. (2016). Determinants of Dividend Payout Ratio: Evidence from Malaysian Public Listed Firms. Journal of Applied Environmental and Biological Sciences, 6(15), 48-54.

Yusniliyana, Y.\&Suhaiza, I. (2016). Determinants of dividend policy of public listed companies in Malaysia. Review of International Business and Strategy,26(1), 88-99. 